\title{
Fundamentals Or Fancies? The Justification Of Returns To Equity From 1950 To 2007
}

Bruce Howard, Wheaton College, USA

\begin{abstract}
Profit-maximizing firms should continue to invest in economic capital to the point where the marginal product of capital equals the marginal cost of financial capital. As such, the returns to shareholders on the right-hand side of the balance sheet should be justified by the returns generated by assets employed on the left-hand side. The author compares the net real after-tax marginal product of capital with returns on U.S. equities over the period 1950 to 2007. The results show that long-term returns on large cap U.S. equities are justified by the marginal product of capital.
\end{abstract}

Keywords: Marginal Product Of Capital; Efficient Equity Markets

\section{INTRODUCTION}

The world is scary; better put it all in cash!

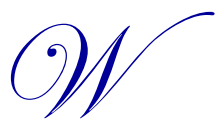

hat would you think if you noticed that most of an investor's holdings were concentrated in money market mutual funds? That was the case when a group of trustees were reviewing the relative weights of participants' investments of their $401 \mathrm{k}$ plan assets. It was observed that an unusually large proportion of plan assets were invested essentially in cash. Further discussion revealed that some participants were reticent to be invested in either bonds or equities. While that might be understandable for retirees committed first and foremost to preservation of capital, most would agree that it is an extreme reaction for employees with 10 or more years of work ahead of them. In the case of these individuals, they had simply lost confidence in the ability of suppliers of financial capital to be compensated for their investment in publicly traded companies.

Even in good economic times, the future is uncertain; but in seasons of economic distress, this uncertainty can take a greater than normal toll on an individual's well-being. As such, it is helpful to remind ourselves of what investing is really all about.

It is a simple story. Investors supply financial capital to businesses. These firms then convert financial capital into assets that, when combined with the abilities and energies of people, create value. If the value created exceeds any value consumed in the process, profits are the result and investors are rewarded accordingly.

If this story is true, then returns to financial capital should be justified by the value created by economic capital. From a balance sheet perspective, returns to assets on the left side of the balance sheet should explain returns to financial capital on the right-hand side. Are returns to equities driven by fundamentals; i.e., the value created by the assets they finance, or are equity returns more the result of fancies?

The specific research question posed in this study is, "Do the returns to assets, as measured by marginal product of capital, justify the returns to equity in the historical context of the United States?" The answer is a qualified 'yes'. 


\section{Related Research}

The relationship between returns to business assets and returns to equity used to finance those assets is well established in the literature. Burton Malkiel credits Alan Greenspan as being the first to use the market value of firms as a determinant of the rate of investment (Malkiel, 1979). Greenspan used capital productivity as one of several parameters examined in attempting to explain stock prices (Greenspan, 1959).

Brainard and Tobin noted "the importance of explicit recognition of the essential interdependences of markets in theoretical and empirical specifications of financial models. Failure to respect some elementary interrelationships - for example, those enforced by balance sheet identities - can result in inadvertent but serious errors of econometric inference and of policy" (Brainard and Tobin, 1968). To that end, Tobin's q ratio incorporates the market value of a firm's equity in the numerator and the replacement cost of a firm's assets in the denominator to explain the firm's inclination to invest in assets (Brainard and Tobin, 1968; Tobin, 1969). In the words of Brainard and Tobin, "another way to state the same point is to say that investment is encouraged when the market yield on equity $r_{k}$ is low relative to the real returns to physical investment" (Brianard and Tobin, 1968, 104).

Jorgenson's neoclassical model of investment implicitly links investment in physical capital with returns to equity if you equate the rental price of capital with the cost of equity (Jorgenson, 1967). ${ }^{1}$ Hayashi provided a helpful synthesis of the neoclassical and q theories of investment (Hayashi, 1982).

Clark (1991) explicitly examined the relationship between returns on equity (stock returns) and return on production capital (investment returns). His work predicts that stock returns and investment returns should be equal. He found that ex-post investment returns and stock returns were highly correlated. In a later study, Clark used returns on physical capital inferred from investment data via a production function to explain stock prices (Clark, 1996). Those results were also encouraging with respect to seeing the link between returns on investment and stock.

Hall theorized that "if firms purchase capital up to the point where there is no further marginal benefit and the firms' securities are equal in value to the value of capital, then the market value of securities measures the quantity of capital (Hall, 1999)." " He concluded that the evidence was supportive of the endogenous investment hypothesis, albeit not definitive.

Diamond pointed specifically to returns on capital as a factor for predicting future stock prices (Diamond, $2000,45)$. "For the long run, the returns to financial assets must reflect the returns on the physical assets that support the financial assets." (Diamond, 2000, 45)

Allen and Gale use a model that equates return on investment with the marginal product of capital in an attempt to explain "bubble and crises" (Allen and Gale, 2000).

Robert Hall, in his Richard T. Ely Lecture "Struggling to Understand the Stock Market", acknowledged this fundamental relationship between returns on assets and equity. "The result is what one might call the real stuff theory of the stock market - the market moves only as much as the quantity of real stuff owned by corporations. Returns earned by shareholders are exactly the marginal product of capital." (Hall, 2001, 5) He concludes that the proposition that the stock market properly values the property owned by corporations, stands up reasonably well in data for the United States over a period of 50 years. He does credit cash flow growth "as the key factor in understanding movements in the stock market" (Hall, 2001, 11).

\footnotetext{
${ }^{1}$ This point is succinctly made by Peter Clark (Clark, 1979). "If output is produced under competitive conditions and technology and can adequately be described by a Cobb-Douglas production function, the desired capital stock at each point in time should be a linear function of $K^{d}=\gamma \frac{p Y}{C}$

$\gamma=$ share of capital in output

$p=$ price of output

$C=$ rental price of capital".

${ }^{2}$ Robert E. Hall, "The Stock Market and Capital Accumulation”, NBER Working Paper Series 7180, http//www.nber.org/papers/w7180, June 1999, abstract.
} 
A related question of whether or not stock prices impact investment has been explored with mixed results. Barro concluded that "stock prices have substantial explanatory power for U.S. investment, especially for long-term samples, and even in the presence of cash flow variables." (Barro, 1990, 115) Morck, Shleifer and Vishny looked at the same question using both firm-specific and aggregate data (Morck, Shleifer and Vishny, 1990). The firmspecific data showed that stock prices added only a little in terms of predicting investment. Aggregate data led them to reject the financing effect of stock prices. That finding was echoed by Blanchard, Rhee and Summers who concluded that "market valuation appears to play a limited role, given fundamentals, in the determination of investment decisions." (Blanchard, Rhee and Summers, 1993, 132) Baker, Stein and Wurgler refined the question by looking at the issue of stock price and investment in terms of a firm's dependence on equity rather than debt for financing (Baker, Stein and Wurgler, 2003). They found a high correlation between equity dependent firms' stock prices and investment.

\section{Contribution Of This Study}

Studies to date acknowledge the theoretical relationship between marginal product of capital and return on financial capital, but only so far as it is integral to an argument for explaining the quantity of capital, the rate of investment in new capital, or the prices of equities. The contribution of this study is that it directly examines the question, "In the United States experience, do the rates of returns on equities equal the rates of marginal product of capital?" If so, then the basic story of investment is valid. As long as capital on the left-hand side of business balance sheets remains productive, shareholders should reap a commensurate return. So how does the story stack up against the evidence?

The annually compounded real net marginal product of capital from 1950 to 2007 was $7.87 \%$. The annually compounded real return on large cap stocks was $7.75 \%$ over that same period of time. The evidence is less convincing when you begin to look at shorter periods of time. The results show that the variability of returns to equity each year is much greater than the variability in rates of marginal product of capital. Given the "animal spirits" that plague the stock markets, that is no surprise, but that variability is something that can certainly "spook" financial investors. The encouraging thing is that the evidence demonstrates that, over time, owners of large cap equities are rewarded for the productivity of the capital they have financed.

Returns on small cap stocks have been substantially higher than the rates of marginal product of capital calculated in this study.

\section{METHODOLOGY}

The basic methodology is to compare annually compounded rates of return on corporate equities with annually compounded rates of marginal product of capital over extended periods of time to see if there is a direct relationship between the two. Using the Cobb-Douglas model, estimates of the rate of gross marginal product can be found by simply dividing capital's share of output by the ratio of capital to output for the private business sector of the U.S. economy from 1950 to 2007 . At a practical level, every production function requires some degree of aggregation. Factories are made up of a host of different assets and sub-production functions. A machine itself consists of a variety of components all interacting in the real-time process of generating output. In this study, the aggregate economy is conceived as one large highly complex production unit.

Von Furstenberg argued for adjusting Tobin's q theory of capital investment to account for income taxes, depreciation and inflation (Von Furstenberg, 1977). To that end, in this study the depreciation rate on capital is deducted from the calculated marginal product yielding the net marginal product of capital. Since corporations pay federal and state taxes on income, the net marginal product of capital is adjusted for the impact of taxes. This yields an estimate for the net marginal product of capital in terms of a nominal percentage value, which is then adjusted for the inflation experienced in a given year as measured by the CPI. The resulting real after tax net marginal product of business capital is compared to the annually compounded rates of return on large and small cap corporate equities, which have also been adjusted for the impact of inflation using the CPI. 


\section{DATA}

The output data used are Bureau of Economic Analysis, Gross Value Added by Sector for Business, reported in current dollars. Capital's share of output is the numerical complement of Labor's share and Labor's share of output is determined by using BEA data on National Income by Type of Income. Compensation of employees is the numerator and National Income, less Proprietors' Income, is the denominator. Proprietors' income is assumed to have the same split between labor and capital shares of total output. Data for stocks of business capital come from BEA Current-Cost Net Stock of Private Fixed Assets, Equipment and Software, and Structures by Type, specifically Private Fixed Assets-nonresidential equipment, software and structures.

Thurow demonstrated the importance of adjusting capital stock measures for utilization rates (Thurow, 1968). Von Furstenberg also incorporated capacity utilization in his adjustments to Tobin's q ratio (Von Furstenbery, 1977). To that end, capital stock measures were adjusted for utilization rates. Industrial production and capacity utilization rates published by the Federal Reserve were used to adjust capital stock from the beginning of that series in 1967 to 2007 . The comparable series for manufacturing was used to adjust capital stock measures from 1950 through 1966 since the total index was not available prior to 1967. This seemed reasonable since the coefficient of correlation between the two series from 1967 to 2007 is .9934 .

Depreciation rates are calculated by taking the depreciation reported in BEA Current-Cost Depreciation of Private Fixed Assets, Equipment and Software, and Structures by Type and dividing that depreciation by the values of the respective capital stocks. Effective rates of taxation on corporate income are calculated by using data from BEA, National Income by Type of Income and dividing corporate income tax by corporate income. Returns on large and small cap equities are those reported in Ibbotson Classic Yearbook 2007. ${ }^{3}$

\section{RESULTS}

The results for the extended period of time (from 1950 to 2007) show that the Cobb Douglas production function does a reasonably good job of justifying the real annual returns on large cap equities. The annually compounded real net marginal product of capital after the period 1950 to 2007 was $7.87 \%$. Over that same period of time, the annually compounded real return on large cap stocks was virtually identical $-7.75 \%$. The robustness of the results is more variable when considering shorter periods of time. Table 1 summarizes the results for various periods of time.

Table 1: Summary Of Results For Large Cap Equities

\begin{tabular}{|c|c|c|c|}
\hline & $\begin{array}{c}\text { Real Annually Compounded } \\
\text { Total Rate Of Return On Large } \\
\text { Company Stocks }\end{array}$ & $\begin{array}{c}\text { Real Annually Compounded } \\
\text { Net MPK After Tax }\end{array}$ & $\begin{array}{c}\text { Ratio Of Annually Compounded } \\
\text { Real Return On Large Company } \\
\text { Stocks To Annually Compounded } \\
\text { Real After Tax Net MPK }\end{array}$ \\
\hline $1950-2007$ & $7.75 \%$ & $7.87 \%$ & 0.98 \\
\hline $1960-2007$ & $5.95 \%$ & $7.66 \%$ & 0.78 \\
\hline $1970-2007$ & $6.16 \%$ & $6.82 \%$ & 0.90 \\
\hline $1980-2007$ & $9.00 \%$ & $8.34 \%$ & 1.08 \\
\hline $1990-2007$ & $7.45 \%$ & $9.95 \%$ & 0.75 \\
\hline
\end{tabular}

(Standard deviation in parentheses)

\section{Discussion Of Results For Large Cap Equities}

The results show that labor's share of income has consistently been around $70 \%$, which implies a consistent capital share of around $30 \%$. This result is comparable with the literature. ${ }^{4}$ Gilchrist and Himmelberg report a mean marginal product of capital $20 \%$ before tax and depreciation (Gilchrist and Himmelberg, 1998). This compares to

\footnotetext{
${ }^{3}$ Ibbotson ${ }^{\circledR}$ SBBI® Classic Yearbook 2007, Morningstar, New York, 2007.

${ }^{4}$ Marcelo Mello provides a helpful justification of this particular result in his paper, "Estimates of the Marginal Product of Capital, 1970-2000", The B.E. Journal of Macroeconomics, Volume 9, Issue 1, 2009, page 5. In that paper he employs a constant share of capital value of 30\%, i.e. the complement of labor's 70\% share. Michael Pakko found a similar result for labor's share of income from 1948 to 2003 and published the August 2004 issue of National Economic Trends, published by The Federal Reserve Bank of St. Louis.
} 
an average of $21.21 \%$ from 1950 to 2007 that we derived in this study. A marginal product of capital of $20 \%$ is, however, notably greater that the $12 \%$ marginal product of capital that is derived by Mankiw in his macroeconomic text (Mankiw, 2007, 225). The primary reason for that difference is that Mankiw uses a capital to output ratio of 2.5 for the economy as a whole, which would include residential and government capital. Residential capital, as a percentage of total capital, averaged 39\% from 1950 to 2007. Government's share of total capital for that same period of time was 24\%. ${ }^{5}$ Mulligan and Threinen compared the marginal product of capital of residential and nonresidential capital from 1930 to 2009 and found that "the marginal product of nonresidential capital, net of depreciation, is more than double the marginal product of residential capital" (Mulligan and Threinen, 2009, 13). This would amply account for Mankiw's lower marginal product of capital for the economy as a whole. Mulligan's and Threinen's reported annual marginal product of nonresidential capital for the period 1950 to 2007, net of depreciation, would average $15.4 \%$ which compares reasonably to the $14.83 \%$ found in this study (Mulligan and Threinen, 2009).

The primary thesis of this study is that returns to large cap equities are related to the marginal product of capital for the business sector of the economy. If that is indeed true, then it would be reasonable to expect a significant degree of correlation between returns on equities with the marginal product of capital. The correlation is positive and increases significantly as you consider multiple year holding period returns. The coefficients of correlation for one-year, five-year, ten-year, and 15-year rolling returns are .351, .393, .546 and .587, respectively. The relationship between returns on equities and marginal product of capital is direct and significant.

Over the extended period of time (from 1950 to 2007), the real annually compounded rate of return on large cap equities $(7.75 \%)$ is virtually identical to the annually real compounded rate of marginal product of capital $(7.87 \%)$. That being the case, there should be a one-to-one correspondence between returns on large cap equities with marginal product of capital, with an expectation that the regression coefficient for stock returns being dependent on marginal product of capital should be very close to a value of one. That, in fact, turns out to be the case with longer run perspectives of the respective returns. While the values for R-square are fairly low for fifteenand ten-year rolling returns (.341 and .298), the respective regression coefficients are .95613 and .92863 with pvalues on the order of .00002 and $.00005 .^{6}$ A summary of these results appears in Table 2.

Table 2: Regression Results For Large Cap Equities

\begin{tabular}{|l|c|c|c|}
\hline & Value Of R-Squared & $\begin{array}{c}\text { Regression Coefficient For Real } \\
\text { Annually Compounded Rate Of } \\
\text { Return On Large Cap Stock }\end{array}$ & Coefficient Of Intercept \\
\hline $\begin{array}{l}\text { 15-year rolling returns } \\
\text { 1950-2007 }\end{array}$ & $0.341(0.039)$ & $\begin{array}{c}0.95613 * * * * \\
(0.20526)\end{array}$ & $\begin{array}{c}-0.00036 \\
(0.01618)\end{array}$ \\
\hline $\begin{array}{l}\text { 10-year rolling returns } \\
\text { 1950-2007 }\end{array}$ & $0.298(0.048)$ & $\begin{array}{c}0.92863 * * * * \\
(0.20795)\end{array}$ & $\begin{array}{c}0.002979 \\
(0.0173733)\end{array}$ \\
\hline $\begin{array}{l}\text { 5-year rolling returns } \\
\text { 1950-2007 }\end{array}$ & $0.165(0.074)$ & $\begin{array}{c}0.892361 * * \\
(0.278520)\end{array}$ & 0.006919 \\
\hline $\begin{array}{l}\text { Annual returns } \\
\text { 1950-2007 }\end{array}$ & $0.123(0.163)$ & $\begin{array}{l}1.4345 * * 24295) \\
(0.51171)\end{array}$ & -0.022703 \\
\end{tabular}

(Standard error in parentheses); $* p<.05 ; * * p<.01 ; * * * p<.001 ; * * * * p<.0001$

The results in Table 2 capture the essence of why investors (and potential investors) in equities might have such angst. The highly significant coefficients of .928 and .959 for 10- and 15-year rolling returns imply a one-toone correspondence between marginal product of capital and return on equity. However, that is only true over the long run and, even then, it accounts for only $30 \%$ of the variation in returns on equity that shareholders have experienced. There are two conflicting messages here:

\footnotetext{
${ }^{5}$ The $39 \%$ average residential share of capital stock and the $24 \%$ average government share of capital from 1950 to 2007 were calculated using BEA estimates of Current-Cost Net Stock of Fixed Assets and Consumer Durable Goods, Table 1.1.

${ }^{6}$ The intercept isn't significantly different from zero. Maddala notes that Mincer and Zarnowitz argue that "the predictor $\mathrm{P}_{\mathrm{t}}$ is called 'efficient' if $\alpha=0$ and $\beta=1$ (or in practice if the sample estimates of $\alpha$ and $\beta$ do not differ significantly from 0 and 1, respectively)."
} 
1. Look at that coefficient! It is virtually equal to one. Take comfort, therefore, shareholders; you will be rewarded commensurately for investing in productive assets.

2. Beware investors! The productivity of the assets that your investment finances only explains $30 \%$ of the year-to-year variability of your return on that share of stock.

Figure 1 is a visual picture of these two messages. It compares the rolling 15-year returns on large cap U.S. equities against the 15-year compounded net real marginal product of capital.

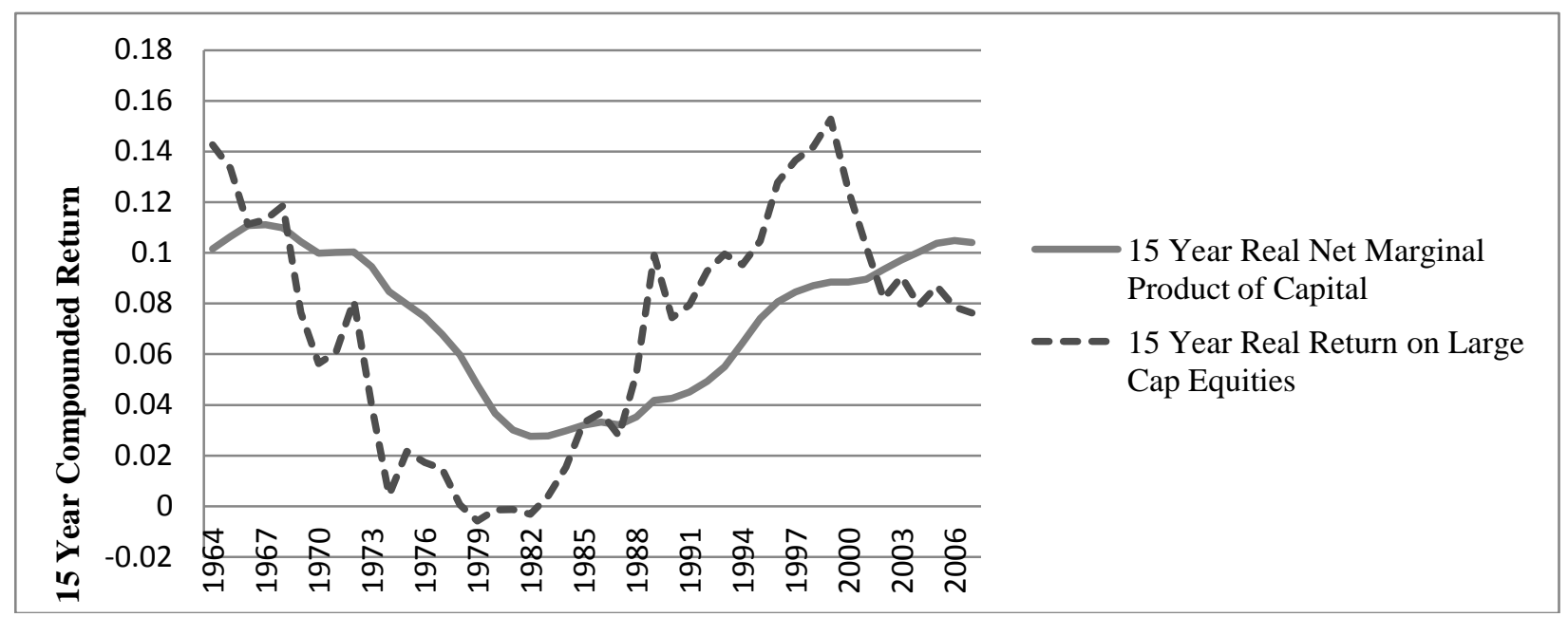

Figure 1: Rolling 15-Year Compounded Real Net Marginal Product

Of Capital And Real Compounded Rate Of Return On U.S. Large Cap Equities (1950-2007)

Visual inspection shows that returns on equity generally follow marginal product of capital, but returns on equity are certainly more volatile. There is clearly something else going on which still needs to be explored. Before 1985, returns on equity were generally lower than would be expected given the marginal product of capital. After 1985, the stock market returns were somewhat higher than would be expected based on the marginal product of capital. Over the 57 years from 1950 to 2007, the market seemed to get it right, but it still begs the question of why the equity returns were systematically lower than marginal product prior to 1985 and systematically higher than marginal product over the next 15 years.

The valuation of equities is certainly a forward-looking proposition. To the extent that investors in equities systematically undervalue the future, it would be reflected in lower annual returns that do not fully incorporate warranted capital appreciation. Perhaps, prior to 1985 , there was a systemic undervaluation of the future. There is a similar phenomenon with respect to long-term U.S. Treasuries.

An expectations theory of the yield curve says that the current yield on a Treasury security is the expected average of the subsequent years' actual returns. Figure 2 shows how well those expectations captured the future experience. In the case of 10-year U.S. Treasuries, the 10 averages of subsequent actual annual yields were systematically higher than expected until 1980 . From that point on, the 10 averages of the subsequent actual annual yields were systematically lower than expected. In other words, prior to 1980, future returns were better than expected; Treasuries undervalued the future. After 1980, returns were lower than expected; Treasuries overvalued the future. 


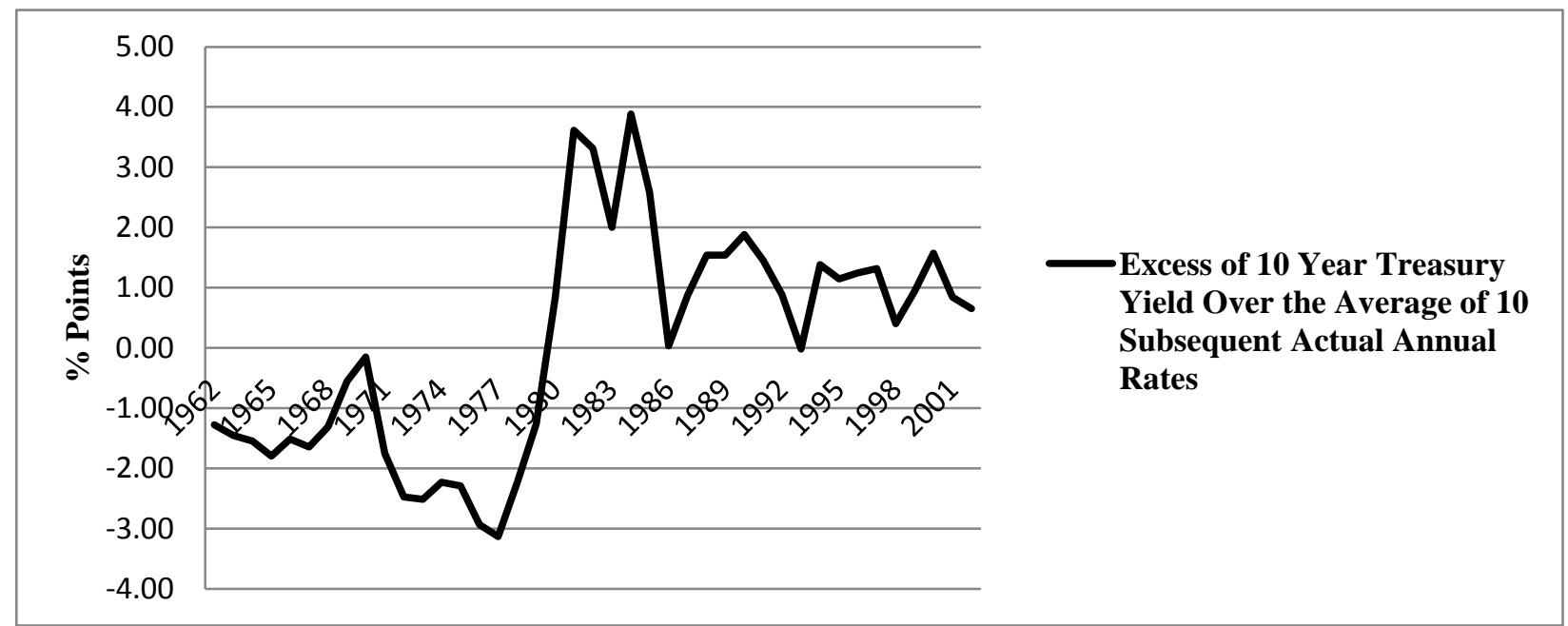

Figure 2: Excess Of 10-Year U.S. Treaury Yield Over The Average Of 10 Subsequent Acutal Annual Rates (1962-2001)

Figure 3 shows how this systematic under-over valuation for 10-year Treasuries mirrors the experience of equities over roughly the same spans of time. It is more of an observation at this point rather than an explanation. It does, however, offer an opportunity for further research.

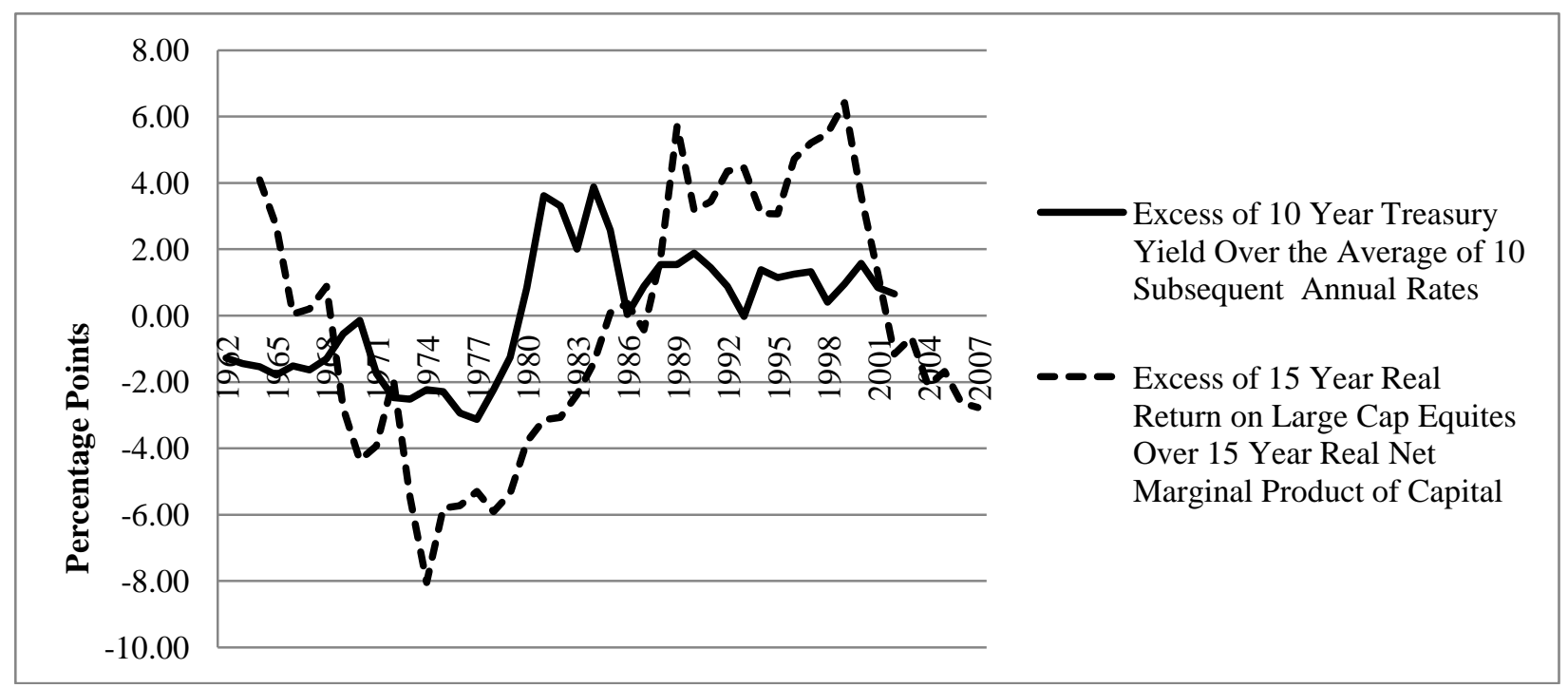

Figure 3: Excess Of 15-Year Real Returns On Large Cap Equities Over 15-Year Real Net Marginal Product Of Capital Compared To Excess Of 10-Year U.S. Treaury Yield Over The Average Of 10 Subsequent Acutal Annual Rates (1962 To 2007)

\section{The Impact Of Intangible Assets}

The capital stock measures created by the Bureau of Economic Analysis traditionally ignore intangible assets as a component of capital. The BEA has attempted to address this deficiency by developing a satellite series of data that capitalizes research and development expenditures. The impact of such treatment increases both the numerator (capital stock) and the denominator (higher reported output since R\&D expenditures aren't treated as an operating expense) of the capital-output ratio. This could have an impact if the ratio of output to capital stock for intangible capital is materially different from all other capital. The data adjusting Business GDP and stocks of 
business capital, by treating Research and Development expenditures as capital investments, are available from 1959 to 2006. Table 3 shows the results of such adjustments for comparable periods of time beginning in 1960 through 2006. The results are somewhat improved with the exception of the period 1980 to 2006 which shows a significantly higher return on large cap equities than would be expected given the marginal product of capital over that period of time.

Table 3: Summary Of Results For Large Cap Equities With Research \& Development Treated As Capital Expenditure

\begin{tabular}{|c|c|c|c|}
\hline & $\begin{array}{c}\text { Real Annually Compounded } \\
\text { Total Rate Of Return On Large } \\
\text { Company Stocks }\end{array}$ & $\begin{array}{c}\text { Real Annually Compounded Net } \\
\text { Mpk After Tax }\end{array}$ & $\begin{array}{c}\text { Ratio Of Annually Compounded } \\
\text { Real Return On Large } \\
\text { Company Stocks To Annually } \\
\text { Compounded Real After Tax } \\
\text { Net Mpk }\end{array}$ \\
\hline $1960-2006$ & $6.05 \%$ & $6.92 \%$ & 0.87 \\
\hline $1970-2006$ & $6.29 \%$ & $5.99 \%$ & 1.05 \\
\hline $1980-2006$ & $9.30 \%$ & $7.43 \%$ & 1.25 \\
\hline $1990-2006$ & $7.82 \%$ & $9.00 \%$ & 0.87 \\
\hline & $(17.25 \%)$ & $(1.69 \%)$ & \\
\hline
\end{tabular}

(Standard deviation in parentheses)

\section{Discussion Of Results For Small Cap Equities}

The focus so far has been on large cap equities. With small cap stocks, the picture is less clear. Small cap equities have performed significantly better than large cap equities over the period 1950 to 2007. Table 4 shows the comparative annually compounded rates of return for large and small cap equities over various periods of time and how those long-term returns compare to the long-term annually compounded marginal product of capital.

Table 4: Comparison Of Large And Small Cap Equities

\begin{tabular}{|c|c|c|c|c|c|}
\hline & $\begin{array}{c}\text { Real Annually } \\
\text { Compounded } \\
\text { Total Rate Of } \\
\text { Return On Large } \\
\text { Company Stocks }\end{array}$ & $\begin{array}{c}\text { Real Annually } \\
\text { Compounded } \\
\text { Total Rate Of } \\
\text { Return On Small } \\
\text { Company Stocks }\end{array}$ & $\begin{array}{c}\text { Real Annually } \\
\text { Compounded } \\
\text { Net MPK } \\
\text { AFTER Tax } \\
\end{array}$ & $\begin{array}{c}\text { Ratio Of } \\
\text { Annually } \\
\text { Compounded } \\
\text { Real Return On } \\
\text { Large Company } \\
\text { Stock To } \\
\text { Annually } \\
\text { Compounded } \\
\text { Real After Tax } \\
\text { Net MPK } \\
\end{array}$ & $\begin{array}{c}\text { Ratio Of Annually } \\
\text { Compounded Real } \\
\text { Return On Small } \\
\text { Company Stock To } \\
\text { Annually } \\
\text { Compounded Real } \\
\text { After Tax Net MPK }\end{array}$ \\
\hline \multirow[t]{2}{*}{1950 to 2007} & $7.75 \%$ & $10.15 \%$ & $7.87 \%$ & 0.98 & 1.29 \\
\hline & $(17.23 \%)$ & $(24.21 \%)$ & $(4.21 \%)$ & & \\
\hline \multirow[t]{2}{*}{1960 to 2007} & $5.95 \%$ & $9.28 \%$ & $7.66 \%$ & 0.78 & 1.21 \\
\hline & $(16.16 \%)$ & $(23.76 \%)$ & $(4.46 \%)$ & & \\
\hline \multirow[t]{2}{*}{1970 to 2007} & $6.16 \%$ & $8.40 \%$ & $6.82 \%$ & 0.90 & 1.23 \\
\hline & $(16.67 \%)$ & $(21.67 \%)$ & $(4.45 \%)$ & & \\
\hline \multirow[t]{2}{*}{1980 to 2007} & $9.00 \%$ & $10.08 \%$ & $8.34 \%$ & 1.08 & 1.21 \\
\hline & $(15.25 \%)$ & $(18.78 \%)$ & $(3.54 \%)$ & & \\
\hline \multirow[t]{2}{*}{1990 to 2007} & $7.45 \%$ & $10.00 \%$ & $9.95 \%$ & 0.75 & 1.01 \\
\hline & $(16.83 \%)$ & $(20.83 \%)$ & $(1.79 \%)$ & & \\
\hline
\end{tabular}

(Standard deviations in parentheses)

The rates of return on small cap equities are significantly higher than would be expected given the rates of marginal product of capital as calculated in this study. It is, however, interesting to see that at least for the periods 1950 to 2007,1960 to 2007,1970 to 2007 and 1980 to 2007, they are consistently higher on the order of $21 \%$ to $29 \%$. This doesn't seem unreasonable. The data in this study are highly aggregated and are more apt to reflect the realities of large, well-capitalized business entities. Smaller firms will have fewer assets relative to large firms and could therefore be expected to have higher marginal products of capital since they are not as far down the path of employed capital. 
Since the ratios of return on small cap equities to marginal product of capital consistently hover in the range of 1.21 to 1.29 from 1950 through 2007, it can reasonably be expected that the regression coefficient of the dependent variable - return on small cap equities - should reflect that same relationship with the independent variable - marginal product of capital. As shown in Table 5, the coefficient is 1.31 , which is quite close to the actual values of 1.21 to 1.29 found in this study, but the statistical significance of the relationship is rather weak; i.e., a Pvalue of .0835 .

Table 5: Regression Results For Small Cap Equities

\begin{tabular}{|c|c|c|c|}
\hline & $\begin{array}{c}\text { Value Of R- } \\
\text { Squared }\end{array}$ & $\begin{array}{c}\text { Regression Coefficient For Real } \\
\text { Annually Compounded Rate Of Return } \\
\text { On Small Cap Stock }\end{array}$ & Coefficient Of Intercept \\
\hline $\begin{array}{c}\text { Annual } \\
\text { Returns 1950- } \\
2007\end{array}$ & $\begin{array}{c}0.0525 \\
(0.2377)\end{array}$ & $\begin{array}{c}1.3166 \\
(0.747258)\end{array}$ & 0.02247 \\
\hline
\end{tabular}

(Standard error in parentheses); ${ }^{*} \mathrm{p}<.05 ; * * \mathrm{p}<.01 ; * * * \mathrm{p}<.001 ; * * * * \mathrm{p}<.0001$

\section{CONCLUSION}

The quest for economic efficiency dictates that firms should continue to invest in assets up to the point where the marginal product of capital is equal to the cost of financial capital used to fund that investment. This implies that returns on equity should correspond to rates of marginal product of capital. Over the period 1950 to 2007, the large cap equities market has been remarkably efficient in that the annually compounded real return on large cap equities over that period of time closely approximates the annually compounded rate of the marginal product of capital net of inflation, depreciation and tax. While this is true for the long run, the year-to-year variations in return on equity are much greater than can be explained by year-to-year variations in the real net marginal product of capital. Furthermore, prior to 1985 , returns on equity were systematically lower than expected given the marginal product capital, but from that point on, the reverse is generally true.

If investing in equities is a long-term proposition, then the results of this study are encouraging. In the long run, shareholders have received their just rewards; however, the results also warn that faith in the expectation of commensurate rewards to shareholders should vary inversely with the time horizon under consideration. There are forces that, other than the value being created from assets employed on corporate balance sheets, impact the year-toyear returns that shareholders enjoy.

The methodology used in this paper is fairly unsophisticated in that it employs highly aggregated data, but perhaps it is the highly aggregated nature of these data that lends itself to a reasonable basis for predicting the cumulative total real returns of the SAP 500 over such an extended period of time. Furthermore, there are some serious questions as to the theoretical justification for using an aggregated production function of any kind. Felipe and Fisher (2003) conclude that "the conditions under which a well-behaved aggregate production function can be derived from micro production functions are so stringent that it is difficult to believe that actual economies satisfy them" (Felipe and Fisher, 2003).

Further research is warranted that specifically addresses the marginal productivity of capital of small cap companies compared to large cap firms. The study could also be expanded to include OECD countries.

\section{AUTHOR INFORMATION}

Bruce Howard, Ph.D., CPA, holds the Carl R. Hendrickson Chair of Business Economics at Wheaton College, Wheaton, Illinois. In that role, his teaching focuses on the intersections of microeconomics, management, finance and accounting. In conjunction with his teaching career, Dr. Howard maintains an active professional association with Tyndale House Publishers, servicing on their Board of Directors. Dr. Howard also serves on the Advisory Board of Performance Trust and Wheaton Wealth Partners. He has work experience in publishing, health care administration and banking. Email: Bruce.howard@wheaton.edu. 


\section{REFERENCES}

1. Abel, A.B. \& Blanchard, O.J. (1986). The Present Value of Profits and Cyclical Movements in Investment. Econometrica, 54(2): 249-273.

2. Allen, A. \& Gale, D. (2000). Bubbles and Crises. The Economic Journal, 110:236-255.

3. Baker, D., DeLong, J.B., \& Krugman, P.R. (2005). Asset Returns and Economic Growth. Brookings Papers on Economic Activity, 1:289-330.

4. Baker, M., Stein, J., \& Wurgler, J. (2003). When Does the Market Matter? Stock Prices and the Investment of Equity-Dependent Firms. The Quarterly Journal of Economics, 118(3):969-1005.

5. Batista, C. \& Potin, J. (2008). Heckscher-Ohlin Specialization and the Marginal Product of Capital, 19762000. Economic Series Working Papers, University of Oxford Department of Economics 357.

6. Barro, R. (1990). The Stock Market and Investment. The Review of Financial Studies, 3(1):115-131.

7. Blanchard, O., Rhee, C., \& Summers, L. (1993). The Stock Market, Profit, and Investment. The Quarterly Journal of Economics, 108(1):115-136.

8. Bond, S. \& Cummins, J.G. (2000). The Stock Market and Investment in the New Economy: Some Tangible Facts and Intangible Fictions. Brookings Papers on Economic Activity, 1: 61-107.

9. Brainard, W. \& Tobin, J. (1968). Pitfalls in Financial Model Building. The American Economic Review, 58(2):99-122.

10. Caselli, F. \& Feyrer, J. (2007). The Marginal Product of Capital. The Quarterly Journal of Economics, 122(2): 535-568.

11. Chatterjee, S. \& Naknoi, K. (2010). The Marginal Product of Capital, Capital Flows, and Convergence. American Economic Review, 100(2): 73-77.

12. Chirinko, B. \& Schaller, H. (2006). Fundamentals, Misvaluation, and Investment. The Real Story. Economic Series. Institute for Advanced Studies. 200.

13. Clark, P., Greenspan, A., \& Goldfeld, S. (1979). Investment in the 1970s: Theory, Performance, and Prediction. Brookings Papers on Economic Activity, 1979(1): 73-124.

14. Cochrane, J.H. (1991). Production-Based Asset Pricing and the Link Between Stock Returns and Economic Fluctuations. The Journal of Finance, 46(1): 209-237.

15. Cochrane, J.H. (1996). A Cross-Sectional Test of an Investment-Based Asset Pricing Model. The Journal of Political Economy, 104(3): 572-621.

16. Denison, E.F. (1993). Robert Gordon's Concept of Capital. Review of Income and Wealth, 39(1): 89-102.

17. Diamond, P. (2000). What Stock Market Returns to Expect for the Future. Social Security Bulletin, 63(2):38-52.

18. Felipe, J. \& Fisher, F.M. (2003). Aggregation In Production Functions: What Applied Economists Should Know. Metroeconomica, 54(2 \& 3): 208-262.

19. Gilchrist, S. \& Himmelberg, C. (1998). Fundamentals and Finance. Macroeconomics Annual. The University of Chicago Press, 13: 223-262.

20. Greenspan, A. (1959). Stock Prices and Capital Evaluation. American Statistical Association. Proceedings of the Business and Economics Statistics Section, 1959:14-26.

21. Gross, D. B. (1998). [Investment: Fundamentals and Finance]: Comment. Macroeconomics Annual. The University of Chicago Press, 13: 262-266.

22. Hall, R. (2000). The Stock Market and Capital Accumulation. Hoover Institution and Department of Economics Stanford University National Bureau of Economic Research, 91(5): 1185-1202.

23. Hall, R. (2001). Struggling to Understand the Stock Market. The American Economic Review, 91(2):1-11.

24. Hayashi, F. (1982). Tobin's Marginal q and Average q: A Neoclassical Interpretation. Econometrica, 50(1): 213-224.

25. Hosek, W.R. \& Zahn, F. (1984). Real Rates of Return and Aggregate Investment. Southern Economic Journal, 51(1): 157-165.

26. Jorgenson, D. (1967). The Theory of Investment Behavior. In Ferber, E. ed., Determinants of Investment Behavior (pp. 129-188). UMI:NBER.

27. Lerner, A.P. (1953). On the Marginal Product of Capital and the Marginal Efficiency of Investment. Journal of Political Economy, 61(1): 1-14.

28. Maddala, G.S. (1977). Econometrics: Economics Handbook Series, New York, McGraw Hill.

29. Malkiel, B. (1979). The Capital Formation Problem in the United States. The Journal of Finance, 
30. 34(2):291-306.

31. Mello, M. (2009). Estimates of the Marginal Product of Capital, 1970-2000. The B.E. Journal of Macroeconomics, 9(1) Article 16:1-28.

32. Metzler, L.A. (1950). The Rate of Interest and the Marginal Product of Capital. Journal of Political Economy, 58(4): 289-306.

33. Miller, E. (2008). An Assessment of CES and Cobb-Douglas Production Functions. Congressional Budget Office Working Paper. 2008-05. http://www.cbo.gov.

34. J. Mincer, J. \& Zarnowitz, V. The Evaluation of Economic Forecasts, in "Economic Forecasts and Expectations," J. Mincer (ed.), National Bureau of Economic Research, New York, 1969.

35. Morck, R., Shleifer, A., Vishny, R., Shapiro, M., \& Poterba, J. (1990). The Stock Market and Investment: Is the Market a Sideshow? Brookings Papers on Economic Activity, 1990(2): 157-215.

36. Mulligan, C.B. \& Threinen, L. (2010). The Marginal Products of Residential and Non-Residential Capital Through 2009. National Bureau of Economic Research Working Paper 15897. http://www.nber.org/papers/w15897.

37. Nordhaus, W.D. (2002). Productivity Growth and the New Economy. Brookings Papers on Economic Activity, 2:2002: 211-265.

38. Pakko, M. (2004). Labor's Share. National Economic Trends. The Federal Reserve of St. Louis. August 2004.

39. Thurow, L.C. (1968). Disequilibrium and the Marginal Productivity of Capital and Labor. The Review of Economics and Statistics, 50(1):23-31.

40. Tobin, J. (1969). A General Equilibrium Approach to Monetary Theory. Journal of Money, Credit and Banking, 1(1):15-29.

41. Von Furstenberg, G., Lovell, M., \& Tobin, J. (1977). Does Market Valuation Matter in the Aggregate? Brookings Papers on Economic Activity, 1977(2): 347-408. 
NOTES 